\title{
Ewa Więcek-Janka
}

Politechnika Poznańska

e-mail: ewa.wiecek-janka@put.poznan.pl

\section{WYKORZYSTANIE CLUSTER OF GREY INCIDENCE W OPRACOWANIU MODELU CELÓW SUKCESORÓW POLSKICH PRZEDSIĘBIORSTW RODZINNYCH \\ USE OF CLUSTER OF GRAY INCIDENCE IN THE DEVELOPMENT OF THE MODEL GOALS SUCCESSORS POLISH FAMILY BUSINESSES}

DOI: $10.15611 / \mathrm{pn} .2017 .499 .31$

JEL Classification: M52, C19

\begin{abstract}
Streszczenie: W artykule przedstawiono wyniki badań nad strukturą celów sukcesorów polskich przedsiębiorstw rodzinnych. Podjęto dwa cele badawcze. Pierwszy dotyczył identyfikacji celów stanowiących podstawę zachowań sukcesorów w kontekście sukcesji. Realizacja przebiegała w dwóch etapach: (1) dwa wywiady grupowe pogłębione $(n=14)$; (2) wywiady indywidualne $(n=27)$. Wynikiem było sporządzenie wstępnej struktury celów sukcesorów. Drugi cel związany był z opracowaniem modelu celów sukcesorów z wykorzystaniem Cluster of Grey Incidence. Osiągnięto go, przeprowadzając następującą procedurę: (1) określenie sekwencji zmiennych charakterystyk; (2) wyzerowanie sekwencji zmiennych; (3) obliczenie miar zachowania się wektorów; (4) obliczenie wartości bezwzględnego stopienia podobieństwa; (5) ustalenie współczynnika doboru i wyodrębnienia zbiorów podobnych charakterystyk systemu. Wyniki wykorzystano do opracowania klastrowego modelu celów sukcesorów polskich przedsiębiorstw rodzinnych. Ponadto wskazano, iż narzędzie Cluster of Grey Incidence spełnia wymagania badań na małych próbach.
\end{abstract}

Słowa kluczowe: struktura celów sukcesorów, sukcesja w firmach rodzinnych, Cluster of Grey Incidence.

Summary: The article presents the results of completed research on the structure of goals of the successors in Polish family enterprises. Two research objectives were undertaken. The first one concerned the identification of goals that are the basis for the behavior of successors in the succession' context. The implementation took place in two stages: (1) two in-depth group interviews $(n=14)$; $(2)$ individual interviews $(n=27)$. The result was a preliminary structure of goals for successors. The second goal was related to the development of a model of goals of successors using the Cluster of Grey Incidence. It was realized by performing the procedure: (1) determining the sequence of variable characteristics; (2) zeroing of variable sequences; (3) calculation of measures of behavior of vectors; (4) calculation of the absolute melting value of similarity; (5) determining the coefficient of selection and isolation of collections of similar characteristics of the system. The results were used to develop 
a clustered model of the goals of the successors of Polish family enterprises. In addition, it was indicated that the selected Cluster of Gray Incidence tool met the requirements of small sample tests.

Keywords: goal's structure of successors, succession in family businesses, Cluster of Grey Incidence.

\section{Wstęp}

Badanie celów, jakimi kierują się sukcesorzy w podejmowaniu decyzji o związaniu się (lub nie) z przedsiębiorstwami rodzinnymi swoich bliskich, jest wymagające ze względu na jakościowy charakter badań, a także trudny dostęp odpowiednio licznej próby, aby móc zastosować wnioskowanie statystyczne. W związku z tym pojawia się potrzeba zastosowania nowych narzędzi metodycznych do analizowania danych empirycznych. Liczba możliwych do uzyskania danych ze względu na specyfikę obiektu badawczego, jakim są przedsiębiorstwa rodzinne, jest ograniczona, a ich pozyskiwanie jest utrudnione. Zatem wnioskowanie na podstawie małej liczby danych wyklucza użycie klasycznych procedur statystycznych [Stamm, Lubinski 2011; Czakon (red.) 2016]. Ponadto należy zwrócić uwagę na fakt, że procedury statystyczne zakładają określone rozkłady prawdopodobieństwa i wymagają danych na odpowiednich skalach pomiarowych, co w przypadku badań przedsiębiorstw rodzinnych jest $\mathrm{z}$ teoretycznego punktu widzenia trudne, jeśli nie niemożliwe. W związku z niekompletnością i ograniczonością uzyskiwanych danych w tego typu badaniach zasadne i celowe jest wnioskowanie i analiza, która wykorzystuje narzędzia i techniki teorii systemów szarych (grey system theory).

Pozyskiwanie danych z przedsiębiorstw rodzinnych jest niełatwe ze względu na utrudniony dostęp do pełnych danych dotyczących firm rodzinnych. Problem dotyczy charakterystyk próbek badawczych, takich jak współczynniki odpowiedzi, wielkość przedsiębiorstwa, jej wiek, podział władzy i własności oraz ogólna dostępność danych. Zwrot odpowiedzi z ankiet jest często zbyt niski [Stamm, Lubinski 2011], aby można było stosować analizy statystyczne w klasycznym ujęciu. Przedsiębiorstwa rodzinne są zazwyczaj mniejsze, a także struktura zysków jest inna niż w firmach nierodzinnych [Westhead, Cowling 1998]. Dostępność danych dotyczących takich przedsiębiorstw jest ograniczona, zwłaszcza w dużych zbiorach danych, gdzie nie wyróżnia się kategorii rodzinności [Bird i in. 2002]. Mimo dużej liczby przedsiębiorstw rodzinnych najczęściej są one własnością prywatną, co ogranicza możliwość dostępu ogólnonarodowych instytucji statystycznych do szczegółowych danych, dlatego też trudno znaleźć pełne informacje nawet w GUS czy EUROSTAT. Zdarza się, że źródła zawierają tylko podstawowe informacje, takie jak dane kontaktowe firmy i datę jej założenia. Kolejnym problemem jest fakt, że właściciele firm i menedżerowie często niechętnie dostarczają poufnych informacji o swojej firmie i rodzinie [Winter $\mathrm{i}$ in. 1998]. Istnieje kilka powodów, dla których członkowie rodziny 
mogą niechętnie uczestniczyć w podstawowych działaniach badawczych z wykorzystaniem ankiet czy wywiadów. Członkowie rodziny zazwyczaj nie chcą, aby tajemnice rodziny były znane [Schulze i in. 2001]. Niechętnie akceptują zbieranie informacji od pracowników [Ward 1997] i chronią wiedzę o ich wewnętrznych działaniach związanych z konkurencją [Donnelley 1988; Zając 2014]. Podobne trudności z pozyskiwaniem danych dotyczą wartości i tradycji rodzin biznesowych, które unikają negatywnej reklamy [Aronoff $i$ in. 1998] i wolą nie mówić niczego, niż powiedzieć coś, co mogłoby zaszkodzić ich reputacji.

\section{Cele sukcesorów w kontekście sukcesji w przedsiębiorstwach rodzinnych}

Cele, jakie towarzyszą sukcesorom podczas podejmowania decyzji o przyszłości, wiążą się ściśle z wartościami rodziny, w jakiej wzrasta sukcesor [Timmons 1999; Griffin 1997; Von Mises 2007]. Badacze podkreślają rolę wartości w rodzinie i organizacjach kształtujących cele młodego człowieka [Zahra, Covin 1995; Lumpkin, Dess 1996; Covin, Miles 1996]. Jak wynika z badań światowych, firmy rodzinne są bardziej konserwatywne, rzadziej inwestują, rzadziej wprowadzają innowacje, posiadają mniej patentów, działają z większą rozwagą, co może oznaczać, że reagują z opóźnieniem na pojawiające się szanse na rynku [Bertrand, Schoar 2006; Bloom, Reenen 2007; Block 2012; Block i in. 2013]. Takie zachowania związane są z obieranymi celami, jakimi niewątpliwie są stabilizacja i bezpieczeństwo. Przeciętne przedsiębiorstwa rodzinne, jak wskazują w swoich badaniach Gómez-Mejía i in. [2010], Graves i Thomas [2004] oraz Schulze z zespołem [2003], rozwijają się wolniej od tych nierodzinnych, $z$ dużym trudem wprowadzają zmiany $i$ innowacje. Tym samym ich potencjał konkurencyjny bywa mniejszy, co jednak kompensuje przywiązanie do tradycji i dbałość o relacje, co podkreśla także Zając [2014]. Czy zatem położenie nacisku na kształtowanie celów długoterminowych przez pokolenie sukcesorów może zmienić opisaną sytuację?

Analiza literatury wykazuje na szerokie omówienie wyborów, jakich dokonują sukcesorzy, a które związane są z cechami temperamentu i osobowości [Barnes 1988; Dumas 1990; Lansberg 1988]. W niektórych badaniach położono nacisk na kompetencje osobowościowe i wskazano na możliwe scenariusze zachowań nestora i sukcesora podczas procesu sukcesyjnego i po nim. Ponadto w swoich badaniach Dumas [1990] wskazuje na wrodzone aspekty relacji nestor-sukcesor. Dumas [1990, s. 172] kładzie nacisk na rolę nestora, a głównie jego osobowości i jego wpływu na wyznaczane cele przez pokolenie sukcesorów. Swagger [1991] w swoich badaniach zwraca ponadto uwagę na wpływ stawianych celów przez sukcesorów i ich oddziaływanie na relacje z innymi członkami rodziny.

Osobowość sukcesora, w odróżnieniu od dzieci z rodzin niebiznesowych, kształtuje się w środowisku mieszanym, gdzie biznes i rodzina to często jedno [Więcek-Janka 2013]. Nawet jeżeli rodzice deklarują rozdzielność tych sfer, to obserwacje, wywiady (zrealizowane przez autorkę w 2016 r.) wskazują na: (1) częste rozmowy 
przy rodzinnym stole na tematy biznesowe, (2) odwoływanie się do priorytetów biznesowych w podejmowaniu decyzji, (3) poszukiwanie konsensusu w podziale czasu między obowiązki rodzinne a biznesowe. Przygotowanie otoczenia i rodziny do przeprowadzenia sukcesji jest najtrudniejszym etapem w cyklu życia każdego przedsiębiorstwa rodzinnego [Otoo i in. 2009; Kets de Vries 1993]. Badacze tej tematyki na świecie zauważyli kilka aspektów, które mają bezpośredni wpływ na skuteczność realizacji procesów sukcesyjnych. Należy je rozpatrywać w odniesieniu do:

- dynamiki rozwoju przedsiębiorstw rodzinnych [Giamarco 2012; Freedman 2012],

- intencji założyciela na początku działalności i przewidywanej strategii rozwoju przedsiębiorstwa [Langevang i in. 2012; DeTienne, Cardon 2012],

- osoby założyciela i jego decyzji odnośnie do roli w firmie po sukcesji [DeTienne, Cardon 2012; Davis 2005],

- kultury organizacyjnej [Sharma, Rao 2000; Oi 2012; Zając 2014],

- kompetencji i planów sukcesora [Chaimahawong, Sakulsriprasert 2013],

- istniejących rozwiązań prawnych w zakresie dysponowania własnością po sukcesji.

Dynamika rozwoju przedsiębiorstwa rodzinnego ściśle wiąże się z planami sukcesora. Są one kluczowe dla prawidłowego przebiegu procesów sukcesyjnych. Jednak to od nastawienia sukcesora oraz od struktury celów, jakie sobie stawia, zależy powodzenie sukcesji.

\section{Metodyka badań}

Badania nad specyfiką diagnozy i oceny celów stawianych przez sukcesorów pierwszej sukcesji w firmach rodzinnych w Polsce zrealizowano w trzecim kwartale 2016 roku w dwóch etapach z wykorzystaniem dwóch metod badawczych: wywiadu pogłębionego grupowego i wywiadu indywidualnego.

Głównym celem pierwszego etapu było wydobycie subiektywnie identyfikowanych celów przez sukcesorów firm rodzinnych (na podstawie ich doświadczeń sukcesyjnych). Wypowiedzi miały charakter otwarty, a uzyskano je podczas dwóch wywiadów grupowych pogłębionych $(2 \mathrm{FGI}) \mathrm{z}$ sukcesorami będącymi w trakcie procesu sukcesji, na różnych jej etapach (łącznie, $n=14$ ). Badani w prowadzonym przez moderatorkę badaniu prezentowali swoje doświadczenia związane z procesem sukcesji wraz z emocjami, jakie się z nim wiążą. W jednym z etapów wywiadu poproszono badanych, aby wymienili indywidualne cele, które sobie stawiają w kontekście nadchodzących zmian. Następnie grupa uzgodniła brzmienie najczęściej wymienianych celów, tworząc ich werbalną interpretację. Uzyskaną listę 20 celów zapisano i przedyskutowano je, a dzięki zastosowaniu reguły eliminacji w procesie podejmowania decyzji zbiorowej powstała lista 10 celów, które uzyskały aprobatę wszystkich uczestniczących w badaniu sukcesorów. Rezultat końcowy badań w postaci listy celów sukcesorskich przedstawia tab. 1.

Drugi etap badań przeprowadzono na 27-osobowej grupie sukcesorów w odstępie 30 dni od pierwszego etapu. Badani ocenili (na skali od 1 do 5) poziom ważności celów z opracowanej miesiąc wcześniej listy. Struktura próby odpowiada strukturze 
Tabela 1. Lista celów stawianych przez sukcesorów przedsiębiorstw rodzinnych

\begin{tabular}{|r|c|l|}
\hline 1 & X1 & samorealizacja \\
\hline 2 & X2 & spełnianie marzeń \\
\hline 3 & X3 & rozwój przez naukę \\
\hline 4 & X4 & posiadanie przyjaciół \\
\hline 5 & X5 & wewnętrzna harmonia \\
\hline 6 & X6 & poszukiwanie doświadczeń biznesowych \\
\hline 7 & X7 & poszukiwanie doświadczeń osobistych \\
\hline 8 & X8 & założenie własnej rodziny \\
\hline 9 & X9 & korzystanie z życia \\
\hline 10 & X10 & zdobycie fortuny \\
\hline
\end{tabular}

Źródło: opracowanie własne.

populacji sukcesorów [Lewandowska i in. 2017], w której udział mężczyzn zarządzających przedsiębiorstwami rodzinnymi jest 3-krotnie większy w stosunku do udziału kobiet na tym stanowisku. Dobór próby należy uznać za kwotowo-celowy.

W badaniu wzięło udział 7 kobiet (1 w wieku do 25 lat; 4 w wieku 26-35 i 2 powyżej 35 lat); 20 mężczyzn (6 w wieku do 25 lat; 10 w wieku 26-35 lat i 4 powyżej 35 lat). Trzy kobiety wśród badanych nie pracują w firmie rodzinnej (będąc jednocześnie sukcesorkami), 1 pracuje na niższym szczeblu zarządzania i 3 pracują na stanowiskach menedżerskich. Wśród badanych mężczyzn 5 nie pracuje w firmie rodzinnej (będąc jednocześnie sukcesorami), 6 pracuje na niższym szczeblu zarządzania, 7 pracuje na stanowisku menedżerskim, 1 zarządza całą firmą. Wśród badanych w wieku do 25 lat (co stanowi 26\% próby), 3 nie pracuje w firmie rodzinnej, pozostałe 4 pracuje na niższych szczeblach zarządzania. Wśród badanych między 26 a 35 rokiem życia (stanowiącymi 55\% badanej próby) 4 nie pracuje w firmie rodzinnej, 4 pracuje na niższych szczeblach zarządzania, a 7 pracuje w firmie rodzinnej na stanowisku menedżerskim. Wśród badanych w wieku powyżej 35 lat (18\% badanej próby) 1 osoba nie pracuje w firmie rodzinnej, 3 osoby zajmują stanowiska menedżerskie i 1 osoba zarządza całą firmą.

Pozyskane dane surowe wskazują zarówno cele uznane za najważniejsze i realizowane, jak i takie, które nie są ważne i badani rzadziej dążą do ich osiągnięcia. Wykorzystując dane surowe, sporządzono jakościowy profil istotności celów jako analizę wstępną do opracowania klastrowego modelu celów sukcesorów w polskich firmach rodzinnych (por. rys. 1).

Celem, który uzyskał najwięcej wskazań (cele oceniane przez respondentów jako bardzo ważne i realizowane w praktyce, tzn. 5), a jednocześnie liczebność tych wskazań była bardzo wysoka (procent najwyższych ocen), należy cel: korzystanie z życia.

Jako ważne i realizowane często badani ocenili dwa cele: zdobycie fortuny i posiadanie przyjaciół. Cele uznane za istotne na poziomie średnim to założenie rodziny i spełnianie marzeń, nieco niżej oceniono samorealizację. Najniżej badani ocenili wybór i osiąganie celów: poszukiwanie doświadczeń osobistych, rozwój przez naukę, 


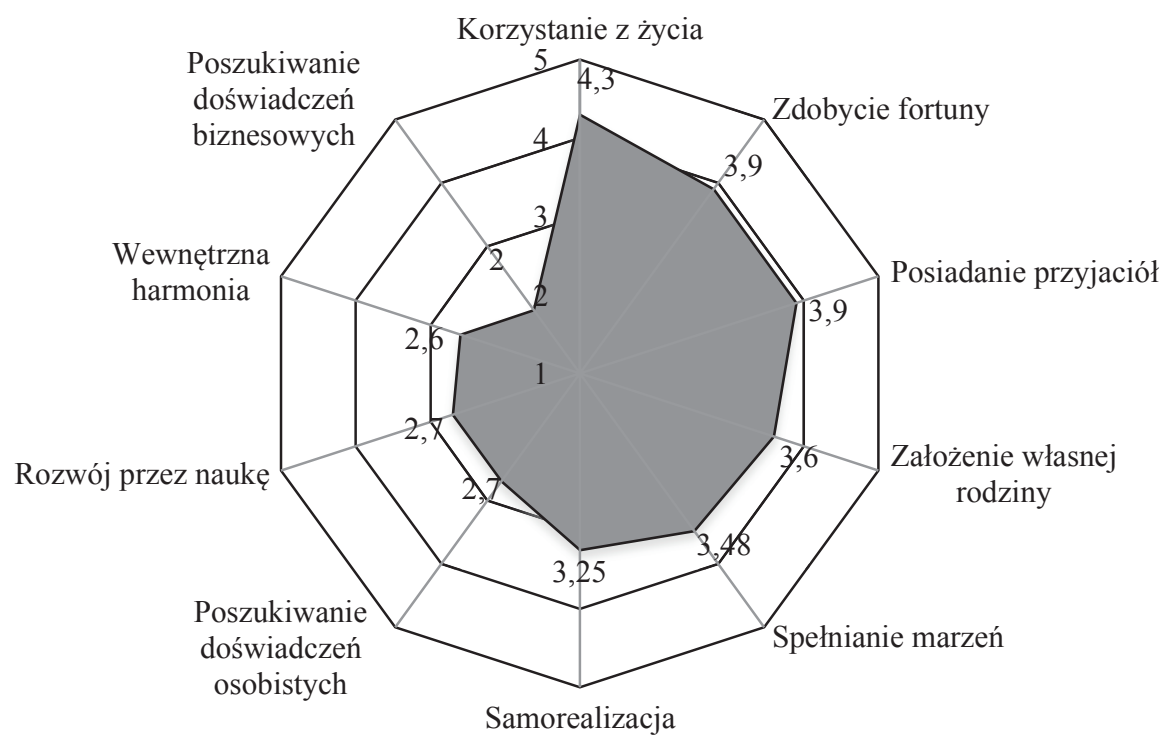

Rys. 1. Profil celów badanych sukcesorów polskich przedsiębiorstw rodzinnych $(n=27)$

Źródło: opracowanie własne.

wewnętrzną harmonię i poszukiwanie doświadczeń biznesowych. Zwłaszcza ostatni opisany cel wydaje się interesujący, można bowiem dostrzec zależność między wiekiem badanych a ich gotowością do poszukiwania nowych doświadczeń biznesowych. Młodzi badani (do 25 roku życia) stawiali sobie za cel zdobywanie doświadczeń biznesowych (25\% badanych), jednak połowa $\mathrm{z}$ nich nie pracowała $\mathrm{w}$ firmie rodzinnej. Pozostali badani nie stawiają sobie celów zdobywania doświadczenia biznesowego i, jak wynikało z rozmowy bezpośredniej, oceniają, że jest ono wpisane w ich codzienną pracę. Model celów z danych surowych zilustrowano na rys. 1 .

\section{Struktura celów sukcesorów opracowana z wykorzystaniem Cluster of Grey Incidence}

Przeprowadzona klasyfikacja określonych przez sukcesorów celów stała się podstawą do opracowania modelu struktury celów sukcesorów z wykorzystaniem metodyki Cluster of Grey Incidence. W oparciu o teoretyczne podstawy [Liu, Lin 2006; Liu, Lin 2010] metoda „szarego klastra” jest stosowana w celu uporządkowania celów tego samego typu w dążeniu do uproszczenia ich listy, a określonej na podstawie badania empirycznego. Poprzez skupienie się na „szarych częstotliwościach” można sprawdzić, czy istnieją określone cele wśród określonej listy dziesięciu celów z bliskimi powiązaniami, tak aby w przyszłości badania mogły wykorzystać indeks połączony lub jeden z tych celów do reprezentowania jego grupy. 
Metodyka realizacji badania składała się z pięciu następujących etapów: (1) określenie sekwencji zmiennych charakterystyk; (2) wyzerowanie sekwencji zmiennych; (3) obliczenie miar zachowania się wektorów; (4) obliczenie wartości bezwzględnego stopienia podobieństwa; (5) ustalenie współczynnika doboru i wyodrębnienia zbiorów podobnych charakterystyk systemu.

(1) Określenie sekwencji zmiennych, tzw. charakterystyk określających zachowanie systemu (system's behavioral characteristics) [Liu, Lin 2006, s. 85-87]:

$$
\begin{aligned}
& X 1=\left(x_{1}(1), x_{1}(2), \ldots, x_{1}(n)\right) ; \\
& X 2=\left(x_{2}(1), x_{2}(2), \ldots, x_{2}(n)\right) ; \\
& \ldots \\
& X 10=\left(x_{10}(1), x_{10}(2), \ldots, x_{10}(n)\right) ;
\end{aligned}
$$

gdzie: $X 1$ - samorealizacja; $X 2$ - spełnianie marzeń; $X 3$ - umożliwienie rozwoju przez naukę; $X 4$ - posiadanie przyjaciół (spędzanie czasu w towarzystwie); $X 5$ - dążenie do wewnętrznej harmonii; $X 6$ - poszukiwanie doświadczeń biznesowych poza firmą rodzinną; $X 7$ - zdobywanie doświadczeń życiowych przez podróżowanie; X8 - założenie własnej rodziny; $X 9$ - korzystanie z życia; $X 10$ - zdobycie fortuny; $n$ - liczba przedsiębiorstw oceniających znaczenie każdej z charakterystyk, $n=27$.

(2) Wyzerowanie sekwencji zmiennych, odejmując od każdej obserwacji wartość początkową sekwencji, dzięki czemu określone zostaje tzw. odbicie wektora obserwacji o zerowej wartości początkowej (zero starting point image) [Liu, Lin 2006, s. 102]:

$$
\begin{aligned}
& X^{0} 1=\left(x_{1}^{0}(1), x_{1}^{0}(2), \ldots, x_{1}^{0}(n)\right) ; \\
& X^{0} 2=\left(x_{2}^{0}(1), x_{2}^{0}(2), \ldots, x_{2}^{0}(n)\right) ; \\
& \ldots \\
& X^{0} 10=\left(x_{10}^{0}(1), x_{10}^{0}(2), \ldots, x_{10}^{0}(n)\right) ;
\end{aligned}
$$

(3) Obliczenie miar zachowania się wektorów przez sumowanie, odejmowanie oraz iloraz ich wartości, zgodnie z formułą [Liu, Lin 2006, s. 104]:

$$
\begin{array}{r}
\left|s_{i}\right|=\left|\sum_{k=2}^{n-1} x_{i}^{0}(k)+\frac{1}{2} x_{i}^{0}(n)\right| \\
\left|s_{i}-s_{j}\right|=\left|\sum_{k=2}^{n-1} x_{i}^{0}(k)-x_{j}^{0}(k)+\frac{1}{2} x_{i}^{0}(n)-x_{j}^{0}(n)\right|
\end{array}
$$

gdzie $i=1,2, \ldots, 10$, a $n=27$.

Poniżej zestawiono obliczone wartości miar zachowania się wektorów: $X^{0} 1, X^{0} 2, \ldots, X^{0} 10$ 


$$
\begin{aligned}
& \left|s_{1}\right|=32,52 ;\left|s_{2}\right|=41,00 ;\left|s_{3}\right|=60,00 ;\left|s_{4}\right|=28,00 ;\left|s_{5}\right|=15,50 ;\left|s_{6}\right|=26,00 ; \\
& \left|s_{7}\right|=63,00 ;\left|s_{8}\right|=68,00 ;\left|s_{9}\right|=19,00 ;\left|s_{10}\right|=25,00 \\
& s_{i}-s_{j} \quad j=1 \quad j=2 \quad j=3 \quad j=4 \quad j=5 \quad j=6 \quad j=7 \quad j=8 \quad j=9 \quad j=10 \\
& i=1 \quad 0 \\
& i=2 \quad 73,5 \quad 0 \\
& i=3 \quad 92,5 \quad 19,0 \quad 0 \\
& i=4 \quad 60,5 \quad 13,0 \quad 32,0 \quad 0 \\
& i=5 \quad 17,0 \quad 56,5 \quad 75,5 \quad 43,5 \quad 0 \\
& i=6 \quad 58,5 \quad 15,0 \quad 34,0 \quad 2,0 \quad 41,5 \quad 0 \\
& i=7 \quad 95,5 \quad 22,0 \quad 3,0 \quad 35,0 \quad 78,5 \quad 37,0 \quad 0 \\
& i=8 \quad 35,5 \quad 109,0 \quad 128,0 \quad 96,0 \quad 52,5 \quad 94,0 \quad 131,0 \quad 0 \\
& i=9 \quad 51,5 \quad 22,0 \quad 41,0 \quad 9,0 \quad 34,5 \quad 7,0 \quad 44,0 \quad 87,0 \quad 0 \\
& i=10 \quad 7,5 \quad 66,0 \quad 85,0 \quad 53,0 \quad 9,5 \quad 51,0 \quad 88,0 \quad 43,0 \quad 44,0 \quad 0
\end{aligned}
$$

(4) Obliczenie wartości bezwzględnego stopienia podobieństwa $\varepsilon_{i j}$ (absolute of grey incidence) między wektorami obserwacji Xi oraz Xj [Liu, Lin 2006, s. 112]:

$$
\varepsilon_{i j}=\frac{1+\left|s_{i}\right|+\left|s_{j}\right|}{1+\left|s_{i}\right|+\left|s_{j}\right|+\left|s_{i}-s_{j}\right|} .
$$

W dalszej części tekstu zestawiono obliczone wartości bezwzględnego stopienia podobieństwa $\varepsilon_{i j}$ między wektorami obserwacji badanego systemu:

$$
\begin{array}{ccccccccccc}
\varepsilon_{j i} & j=1 & j=2 & j=3 & j=4 & j=5 & j=6 & j=7 & j=8 & j=9 & j=10 \\
i=1 & 1 & & & & & & & & \\
i=2 & 0,503 & 1 & & & & & & & \\
i=3 & 0,503 & 0,843 & 1 & & & & & & \\
i=4 & 0,504 & 0,843 & 0,736 & 1 & & & & & \\
i=5 & 0,742 & 0,504 & 0,503 & 0,506 & 1 & & & & \\
i=6 & 0,504 & 0,819 & 0,719 & 0,965 & 0,506 & 1 & & & \\
i=7 & 0,503 & 0,827 & 0,976 & 0,724 & 0,503 & 0,709 & 1 & & \\
i=8 & 0,741 & 0,502 & 0,502 & 0,503 & 0,617 & 0,503 & 0,502 & 1 & & 1 \\
i=9 & 0,505 & 0,735 & 0,661 & 0,842 & 0,507 & 0,868 & 0,654 & 0,503 & 1 & \\
i=10 & 0,886 & 0,504 & 0,503 & 0,505 & 0,814 & 0,505 & 0,503 & 0,686 & 0,506 & 1
\end{array}
$$

(5) Określono wartość współczynnika podobieństwa $r$ na poziomie wysokim, tzn, $r=0,80$ i wyodrębniono zbiory podobnych charakterystyk systemu, dla których zachodzi relacja $\varepsilon_{i j} \geq 0,80$. 
Uzyskano trzy zbiory celów. Do pierwszego z nich zaliczono cele: $X 1, X 5, X 10$. Drugi zbiór zawiera cele: $X 2, X 3, X 4, X 6, X 7, X 9$. Trzeci jednoelementowy obejmuje cel $X 8$.

Wyniki uzyskane dla poszczególnych zbiorów są następujące:

$$
\begin{aligned}
& \text { I.X1,X5,X10 } \\
& \varepsilon_{1,10}=0,886 \\
& \varepsilon_{5,10}=0,814 \\
& \text { II.X2,X3,X4,X6,X7,X9 } \\
& \varepsilon_{23}=0,843 ; \varepsilon_{24}=0,843 ; \varepsilon_{26}=0,819 ; \varepsilon_{27}=0,827 \\
& \varepsilon_{49}=0,842 \\
& \text { III. } X 8
\end{aligned}
$$

\section{Podsumowanie}

Realizowanie w przyszłości badań przedsiębiorstw rodzinnych zgodnie z opracowaną metodyką wymaga spojrzenia na zaproponowaną listę celów sukcesorskich pozyskanych podczas badań metodą Focus Group Interview (FGI) jako możliwą do skrócenia metodą the Cluster of Grey Incidence. Autorce udało się je przeprowadzić. Skrócenie listy celów ma swoje praktyczne uzasadnienie. Uznano, że badanie pełnej listy celów w kolejnych (bardziej licznych badaniach) mogłoby prowadzić do błędów związanych choćby z różną interpretacją celów wśród badanych sukcesorów, ponadto zwiększałoby koszty i wydłużało czas badań.

Po wykonaniu badania FGI (w pierwszym etapie uzyskano dwadzieścia celów: C1-C20, w drugim ograniczono liczebność do dziesięciu: $X 1-X 10)$ zastosowano the Cluster of Grey Incidence i przeprowadzono klastrowanie dla współczynnika $r=0,8$, w którym uzyskano 3 klasy zmiennych. Uzyskany model poddano jakościowej oce-

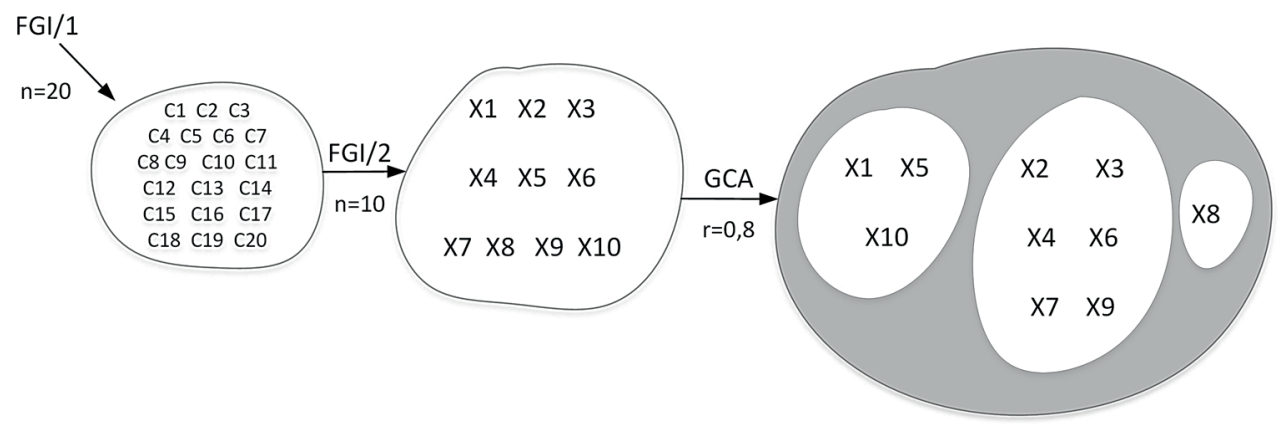

Rys. 2. Przebieg procesu badawczego z wykorzystaniem GCA

Źródło: opracowanie własne. 
nie, która pozwoliła uznać badane zmienne za współbieżne w ramach każdego z klastrów. Przebieg tego procesu badawczego pokazano na rys. 2.

Na podstawie uzyskanych wyników sporządzono model struktury celów sukcesorów. Model zawiera trzy klasy celów, które mają wysokie wewnętrzne wskaźniki podobieństwa (por. rys. 3).

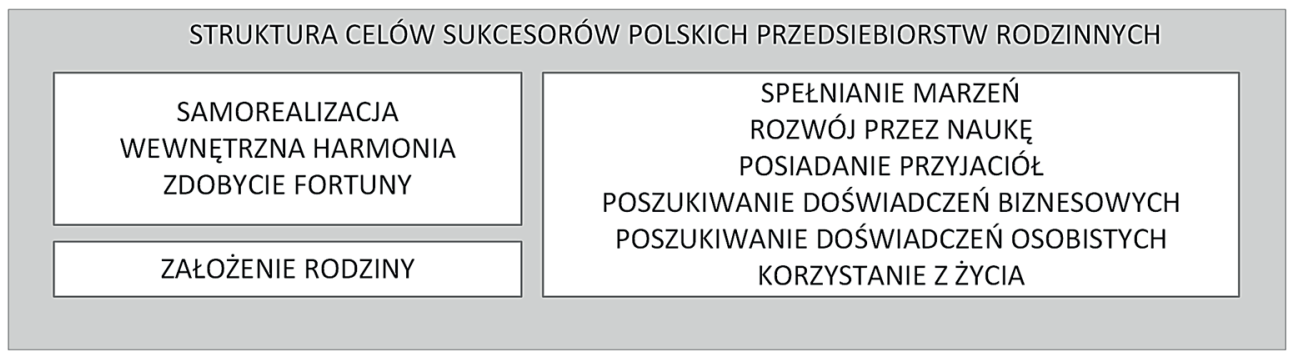

Rys. 3. Model struktury celów sukcesorów polskich przedsiębiorstw rodzinnych opracowany z wykorzystaniem GCA

Źródło: opracowanie własne.

Trzy zbiory celów, jakie stawiają sobie sukcesorzy polskich przedsiębiorstw rodzinnych, informują o tym, które cele mają bliskie powiązania, co w przyszłości pozwoli na wybranie reprezentantów każdego z klastrów do kolejnych badań.

Założenie rodziny $(X 8)$ jest celem, który występuje jako odrębna kategoria i nie ma żadnego bliskiego powiązania z innymi celami. Pozostałe dwa zbiory można potraktować jako wewnętrznie spójne. Samorealizacja $(X 1)$, wewnętrzna harmonia (X5) i zdobycie fortuny (X10) to cele mogące wspólistnieć w kształtowaniu zrównoważonego rozwoju osobistego w perspektywie długoterminowej. Są one obierane przez badanych jako związane ze sferą pozaracjonalną. Cel $X 10$ (zdobycie fortuny), jak interpretowali badani, jest celem nieuchwytnym i dalekosiężnym. Trzeci zbiór celów wiąże się z krótszą perspektywą; dotyczy zachowań i podejmowanych działań nastawionych na szybkie wyniki i zaspokojenie potrzeb hedonistycznych.

Chcąc wykorzystać wyniki klastrowania, np. w realizowanych badaniach na dużych próbach z zastosowaniem narzędzi statystycznych, należałoby wziąć pod uwagę zmniejszoną liczbę celów. Wnikliwe analizy dotyczące od trzech do pięciu celów mogą przynieść wyniki zbliżone do badania wyjściowych dziesięciu celów sukcesorów polskich przedsiębiorstw rodzinnych podczas procesu sukcesji.

\section{Literatura}

Aronoff C.E., Astrachan J.H., Ward J.L., 1998, Developing Family Business Policies: Your Guide to the Future, Marietta, GA: Family Enterprise Publishers.

Barnes L.B., 1988, Incongruent hierarchies: Daughters and younger sons as company CEOs, Family Business Review, no. 1, s. 1-21. 
Bertrand M., Schoar A., 2006, The role of family in family firms, J. Econ. Perspect, no. 20, s. 73-96.

Bird B., Welsch H., Astrachan J.H., Pistrui D., 2002, Family business research: The evolution of an academic field, Family Business Review, vol. 15(4), s. 337-350.

Block J.H., 2012, R\&D investments in family and founder firms: An agency perspective, Journal Bussines, Ventura, no. 27, s. 248-265.

Block J.H., Miller D., Jaskiewicz P., Spiegel F., 2013, Economic and technological importance of innovations in large family and founder firms: an analysis of patent data, Family Business Review, no. 26 , s. $180-199$.

Bloom N., Van Reenen J., 2007, Measuring and explaining management practices across firms and countries, Q. J. Econ., no. 122, s. 1351-1408.

Chaimahawong V., Sakulsriprasert A., 2013, Family Business Succession and Post Succession Performance: Evidence from Thai SMEs, International Journal of Business and Management, vol. 8, no. 2, s. 19-28.

Covin J.G., Miles M.P., 2006, Corporate entrepreneurship and the pursuit of competitive advantage, [w:] Zahra S. (red.), Corporate Entrepreneurship and Growth, Edward Elgar Publishing Ltd, s. 47-63.

Czakon W., 2016, (red.), Podstawy metodologii badań w naukach o zarządzaniu, Wydawnictwo Nieoczywiste.

Davis J., 2005, Changes at the top. Are you ready?, Behavioral Health Management, no. 25 (6), s. 23-28.

DeTienne D.R., Cardon M.S., 2012, Impact of founder experience on exit intentions', Small Business Economics, no 38, s. 351-374.

Donnelley R.G., 1988, The family business, Family Business Review, vol. 1(4), s. 427-445.

Dumas C.A., 1990, Preparing the New CEO: Managing the father-daughter succession process in family businesses, Family Business Review, no. 3, s. 169-181.

Freedman E., 2012, Building the talent pipeline for future leaders' Financial Executive, Family Business Review, November, s. 9-91.

Giamarco J., 2012, The three levels of family business succession planning', Journal of Financial Service Professionals, March, s. 59-69.

Gómez-Mejía L.R., Makri M., Larraza-Kintana M.L., 2010, Diversification decisions in family-controlled firms, Journal of Managing Studies, no. 47, s. 223-252.

Graves C., Thomas J., 2004, Internationalization of the family business: A longitudinal perspective, International Journal Global of Small Business, 2004, no. 1, s. 7-27.

Griffin R.W., 1997, Podstawy zarzadzania organizacjami, Wydawnictwo Naukowe PWN, Warszawa.

Kets de Vries M.F.R., 1993, The dynamics of family controlled firms: The good news and the bad news, Organizational Dynamics, no. 21, s. 59-71.

Langevang T., Namatovu R., Dawa S., 2012, Beyond necessity and opportunity entrepreneurship: motivations and aspirations of young entrepreneurs in Uganda, International Development Planning Review, no. 34 (4), s. 439-459.

Lansberg I., 1988, The succession conspiracy, Family Business Review, no. 1, s. 119-143.

Lewandowska A., Więcek-Janka E., Hadryś-Nowak A., Wojewoda M., 2016, Model pięciu poziomów definicyjnych firm rodzinnych. Podstawy metodyczne $i$ wyniki badań firm rodzinnych $w$ Polsce, Instytut Biznesu Rodzinnego, Poznań.

Liu S., Lin Y., 2006, Grey Information Theory and Practical Application, Springer, London.

Liu S., Lin Y., 2010, Grey Systems Theory and Application, Springer, Berlin.

Lumpkin G.T., Dess G.G., 1996, Clarifying the entrepreneurial orientation construct and linking it to performance, Academic Management Review, 1996, no. 21, s. 135-172.

Oi M., 2012, Adult adoptions: Keeping Japan's family firms alive, http://www.bbc.co.uk/news/magazine-19505088.

Otoo K.N., Osei-Boateng C., Asafu-Adjaye P., 2009, The labor market in Ghana', Accra, Ghana: Labor Research and Policy Institute. 
Schulze W., Lubatkin M.H., Dino R.N., 2003, Toward a theory of agency and altruism in family firms, The Journal of Business Venturing, vol. 18, no. 4, s. 473-490.

Schulze W.S., Lubatkin M.H., Dino R.N., Buchholtz A.K., 2001, Agency relationships in family firms: Theory and evidence, Organization Science, vol. 12(2), s. 99-116.

Sharma P., Rao A.S., 2000, Successor attributes in Indian and Canadian family firms: A comparative study, Family Business Review, no. 13, s. 312-330.

Stamm I., Lubinski C., 2011, Crossroads of family business research and firm demography - a critical assessment of family business survival rates, Journal of Family Business Strategy, vol. 2(3), s. 117-127.

Swagger G., 1991, Assessing the successor generation in family businesses, Family Business Review, 1991, no. 4, s. 397-411.

Timmons J.A., 1999, New Venture Creation: Entrepreneurship in the 21th centuries (6th edition), Homewood, IL.

Von Mises L., 2007, Ludzkie działanie: traktat o ekonomii, Instytut Ludwiga von Misesa, Warszawa.

Ward J.L., 1997, Growing the family business: Special challenges and best practices, Family Business Review, vol. 10(4), s. 323-337.

Westhead P., Cowling M., 1998, Family firm research: The need for a methodological rethink, Entrepreneurship Theory and Practice, vol. 23(1), s. 31-56.

Więcek-Janka E., 2013, Wiodące wartości w zarządzaniu przedsiębiorstwami rodzinnymi, Wydawnictwo Politechniki Poznańskiej, Poznań.

Winter M., Fitzgerald M.A., Heck R.K., Haynes G.W., Danes S.M., 1998, Revisiting the study of family businesses: Methodological challenges, dilemmas, and alter-native approaches, Family Business Review, vol. 11(3), s. 239-252.

Zahra S.A., Covin J.G., 1995, Contextual influences on the corporate entrepreneurship-company performance relationship in established firms: a longitudinal analysis, Journal of Business Venturing, vol. 10, no. 1, s. 43-58.

Zając C., 2014, Skuteczne zarządzanie kapitałem ludzkim jako czynnik sukcesu przedsiębiorstwa, Zarządzanie i Finanse, Uniwersytet Gdański, vol. 12, nr 1, s. 195-207. 